
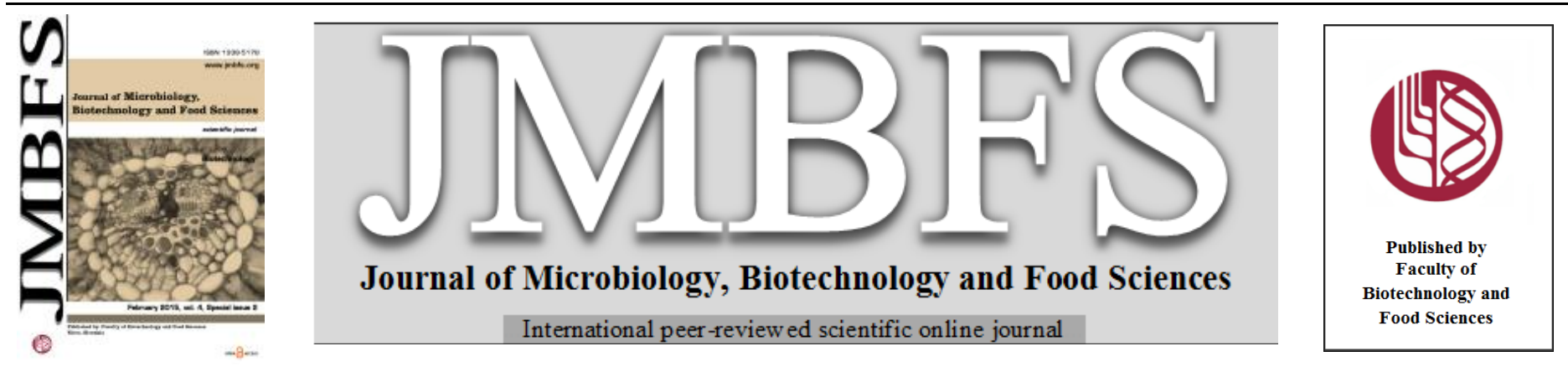

\title{
ACUTE TOXICITY OF METALS: NICKEL AND ZINC TO PARAMECIUM BURSARIA AND ITS ENDOSYMBIONTS
}

\section{Patrycja Zagatal ${ }^{1}$,Marta Kopańska ${ }^{2}$, Magdalena Greczek-Stachura ${ }^{1}$, Tomasz Burnecki ${ }^{1}$}

\author{
Address(es): MSc. PatrycjaZagata \\ ${ }^{1}$ Pedagogical University of Cracow, Faculty of Geography and Biology, Institute of Biology, Department of Plant Physiology, Podchorazych 2, 30-084 Cracow, \\ Poland, +48 126626720 \\ ${ }^{2}$ Pedagogical University of Cracow, Faculty of Geography and Biology, Institute of Biology, Department of Animal Physiology and Toxicology, Podbrzezie 3, 31-054 \\ Cracow, Poland, +48 126626720 .
}

*Corresponding author: patrycjazagata@gmail.com

doi: 10.15414/jmbfs.2015.4.special2.128-131

ARTICLE INFO

Received 4. 11. 2014

Revised 10. 12. 2014

Accepted 17. 12. 2014

Published 2. 2. 2015

$\underline{\text { Regular article }}$ open $\partial_{\text {ACCESS }}$

\begin{abstract}
Paramecium bursaria is an unicellular organism, widely distributed in the freshwater environment, where heavy metals are common contaminants. The ciliates, also including Paramecium bursaria, are a very abundant group in aquatic ecosystems, what makes them effective biological indicators of water pollutants. Paramecium bursaria is the only Paramecium which has evolved a mutualistic relationship with algae and it harbors these endosymbionts in its own cytoplasm. The algae are also very effective bioindicators of some pollutants because of their ability to biosorption and bioaccumulation of heavy metals. The aim of this study was to determine the acute toxicity of two metals' compounds: nickel chloride $\left(\mathrm{NiCl}_{2}\right)$ and zinc chloride $\left(\mathrm{ZnCl}_{2}\right)$ to Paramecium bursaria and its endosymbionts. The ciliates were incubated in solutions with $5 \times 10^{-8}$ to $5 \times 10^{-2} \mathrm{~g} / \mathrm{dm}^{3}$ of $\mathrm{NiCl}_{2}$ and with $5 \times 10^{-8}$ to $5 \times 10^{-2} \mathrm{~g} / \mathrm{dm}^{3}$ of $\mathrm{ZnCl}_{2}$, at the temperature of $18^{\circ} \mathrm{C}$, in the light/dark conditions (12L/12D). Microscopic observations of cell divisions rate, cell shape changes as well as the swimming behavior, were conducted after 24, 48, 72 and 120 hours of incubation in the tested solutions and were compared to the control sample. Microscopic observations revealed the lethal doses for both compounds, for nickel chloride $5 \times 10^{-5} \mathrm{~g} / \mathrm{dm}^{3}$ and for zinc chloride $5 \times 10^{-3}$. These observations also revealed that in lesser concentrations than the lethal one, the slowdown and characteristic movements occur after metal addition. The PEA measurements of Fv/Fm parameter were carried out within 4 days, the first one after 24 hours of incubations. The results of this investigation has given us a view of a fluorescence efficiency by revealing that both compounds solutions can have the stimulating effect on Photosystem II, because the lowest fluorescence efficiency was measured in control samples.
\end{abstract}

Keywords: Nickel chloride, zinc chloride, acute toxicity, Paramecium bursaria, cell immobilization, fluorescence efficiency, PEA

\section{INTRODUCTION}

Heavy metals are common in aquatic ecosystems and toxic at certain concentrations to most organisms living there. The occurrence of these contaminations is a result of draining final effluents of waste treatment plants, and their concentrations increase extremely in highly industrialized areas (Lester, 1983; Madoni, 1999). Heavy metals contaminations of freshwater systems is a worrying problem, because of the environmental damages. Thus, it is the object of national agencies' interest. In the last decades, governments have promulgated strict regulations to guarantee the high quality of drinking water. Some metals are very harmful to freshwater organisms, such as cadmium or lead. On the other hand, metals like iron, copper, zinc or nickel, though they are essential components of living cells, at certain concentrations can be dangerous (Fraile $\boldsymbol{e} t$ al., 2005). Aquatic environments include both fractions, soluble and in particulate matter (Violante et al., 2010). The way in which heavy metals affect the microorganisms is not clear. Scientists suggest metals block some enzyme systems or can interfere with some important cellular metabolites of protozoa and bacteria (Morgan and Lackey, 1958). Metallothioneins are ubiquitous low molecular weight proteins and polypeptides of extremely high metal and cysteine content which give rise to metal-thiolate clusters (Carpene et al., 2007). They are localized to the membrane of the Golgi apparatus. Their function is to bind, store, transport and detoxify metals, which in general means that they protect cells against toxicity of heavy metals (Dar et al., 2013). Metallothioneins are cells' components of vast range of taxonomic groups, ranging from prokaryotes to mammalian (Vasak, 2005).

Nickel is one of the major elements of Earth, constituting about $2 \%$ by weight and it is the $5^{\text {th }}$ most abundant element by weight after iron, oxygen, magnesium and silicon. Nickel is a silvery-white, hard, malleable and ductile metal. It belongs to transition metals, what makes it resistant to corrosion by air, water and alkali and that is why nickel has extensive industrial application (Cempel and Nikel, 2005). In organisms we can find nickel in active sites of enzymes, for example in ureases, which occur in cells of plants, bacteria, fungus, algae and invertebrates. Furthermore, nickel is a component of a few bacteria enzymes, such as hydrogenases (Al-Mjeni, 2002). Nickel and its compounds can be responsible for variety types of cancer in rodents and are listed as possible causative agents for occupational or environmental cancer in man (Dunnick $\boldsymbol{e t}$ al., 1995). The most significant and most often reaction of human on nickel is allergy. Sensitization might occur from any of the numerous metal products in common use, such as coins, jewelry and even mobile phones. Of the general population, approximately $8-10 \%$ of women and $1-2 \%$ of men are sensitive to nickel. Symptoms of nickel sensitivity are erythema, eczema and lichenification of hands and other areas of the skin that contact nickel. Nickel allergies are marked by itch and red skin. Many studies have demonstrated that nickel metal dust and some nickel compounds are extremely potent carcinogens after inhalation and can be responsible for higher chances of development of lung, nose or larynx cancer (Torres et al., 2009). Its toxicity toward freshwater ciliates has not been well known yet. Zinc makes up about 75 ppm of the Earth's crust, making it the 24th most abundant element. Zinc is a bluish-white, lustrous and diamagnetic metal. It is hard and brittle. Zinc is most commonly used as an anticorrosion agent (Batty et al., 2010). It is an essential trace element for all living beings. The element has multiple intracellular functions as a catalyticor structural constituent of more than 300 enzymes (Vallee and Falchuk, 1993; Vallee and Maret, 1993). Moreover, it serves structural ions in transcription factors and is stored and transferred in metallothioneins (Nappi, 2014). Although humans can handle proportionally large concentrations of zinc, too much zinc can still cause eminent health problems, such as stomach cramps, skin irritations, vomiting, nausea and anaemia. Very high levels of zinc can damage the pancreas and disturb the protein metabolism, and cause arteriosclerosis. Extensive exposure to zinc chloride can cause respiratory disorders (Lenntech, 2010). Paramecium bursaria (Peniculia, Oligohymenophorea) is an unicellular organism, belonging to ciliates, which play a significant role in aquatic ecosystems (Lynn, 2008). Ciliates are considered to be cosmopolitan organisms. They can be easily found in various types of watercourses and bodies of stagnant water (Dryl, 1973). This taxonomic group is also a component of microplankton and microbenthic 
(Fenchel, 1987). Ciliates are mostly fed on bacteria and they are prey of organisms of higher taxons as well. That is why they represent important links in the trophic chains, where they mediate the flow both of biological substances and energy from a lower level to a higher one (Carins et al., 1980). Additionally, they play an essential role in the purification processes of both aerobic and anaerobic biological wastewater treatment systems. Their sensitivity to environmental changes suggested their use as biological indicators of water pollution (Nicolau et al., 1999). Paramecium bursaria cells possess hundreds of algae cells in individual perialgal vacuoles (Hoshina et al., 2009). It has evolved a mutualistic relationship with algae, which were also used in this study as bioindicators of toxicities of nickel and zinc. Chlorella vulgaris, which represents one of many possible symbiotic species of Paramecium bursaria, has received much attention in recent years because of its biosorption and bioaccumulations of heavy metals. In this way it can be potentially used in treatment of sewage loaded with toxic heavy metals (Wase $\boldsymbol{e t}$ al., 1997). The aim of this study was to determine the sensitivity of Paramecium bursaria and its endosymbionts to two compounds: nickel (II) chloride and zinc chloride by microscopic observation of its behavior and by measuring PEA parameters $\mathrm{Fv} / \mathrm{Fm}$ what gives us a view of fluorescence efficiency. The $\mathrm{Fv} / \mathrm{Fm}$ is the ratio of variable fluorescence to maximal fluorescence. This is a measure of the maximum efficiency of PSII, when all PSII centers are open. Fv/Fm can be used to estimate the potential efficiency of PSII by taking dark-adapted measurements (Lepedus et al., 2012).

\section{MATERIAL AND METHODS}

In this study we used a strain of Paramecium bursaria collected in the Institute of Biology, Pedagogical University of Kraków. Cells were cultured in lettuce medium according to Sonneborn (1970) including the bacteria Klebsiella pneumoniae as food, at the temperature of $18^{\circ} \mathrm{C}$, in the light/dark conditions (12L/12D). The single cells were picked from the sample by micropipette and placed on a slide. Each slide includes three cells of the studied organism. The ciliates were incubated in solutions with $5 \times 10^{-8}$ to $5 \times 10^{-2} \mathrm{~g} / \mathrm{dm}^{3}$ of $\mathrm{NiCl}_{2}$ and with $5 \times 10^{-8}$ to $5 \times 10^{-2} \mathrm{~g} / \mathrm{dm}^{3}$ of $\mathrm{ZnCl}_{2}$. To determine the toxicity of these two compounds we carried out observations of the rate of cell division, cell shape, morphology and behavior of paramecia after 24, 72 and 120 hours of incubation in different concentrations under constant conditions. To determine the influence of metals on fluorescence efficiency, the PEA measurements were carried out within 4 days, the first after a 24-hour incubation, using Handy PEA (Hansatech Instruments Ltd. Kinga Lynn, Norfolk, England). Each sample was performed the same way and included the same number of cells. The liquid material was placed in $2 \mathrm{ml}$ glass samples and incubated in darkness for 5 minutes. Then the sample was treated with light and measurement was carried out within $10 \mu \mathrm{s}-30$ ms. Nickel (II) chloride and zinc chloride were used as sources for heavy metals. Statistical analysis of the data was carried out using a Tukey's test with p-value < 0.05 .

\section{RESULTS}

In this study we carried out microscopic observations of the rate of cell division, cell shape, morphology and behavior of paramecia after 24, 72 and 120 hours of incubation in different concentrations under constant conditions. According to table, we can see various cell reactions after nickel (II) chloride addition. Occurrence of these reactions depended on the concentration of nickel. We used different concentrations of nickel from $5 \times 10^{-8}$ to $5 \times 10^{-2} \mathrm{~g} / \mathrm{dm}^{3}$ and a control sample. The first reaction we were observing was the rate of cell divisions. It can be easily noticed that in the lowest concentrations cells were dividing similarly to the control sample. The second reaction was an avoiding reaction and rotary movements. The avoiding reaction could be noticed at once in higher concentrations, and after around 10 minutes in the lethal concentration, which was $5 \times 10^{-5} \mathrm{~g} / \mathrm{dm}^{3}$. The avoiding reaction did not occur in lower concentrations. The next reaction was cell immobilization. Nickel is known as one of the most effective immobilization agent for protozoa. In this study cell immobilization was depended of course on nickel concentration and occurred the faster if the concentration was higher. The immobilization did not occur in concentrations lower than the lethal one. The cell deformation and death occurred in higher concentrations and in the lethal after around 1 hour (Table 1). According to the second table, we also observed various cell reactions depending on the concentration of zinc. Additionally, in this table we can see changing of cell color. The first reaction - cell divisions - presents similarly to that in the case of nickel. It increases with the decrease of zinc concentration. Avoiding reaction occurred at once at the highest concentrations and after a few minutes in lower In this case we observed changing in cell color, so in lethal concentrations color has changed from green to gray. In this case we also observed reversal ciliary beat, swimming backward, pivoting, circling and forward movement to a new direction, and the time of occurrence depended of zinc concentration. Lethal concentrations of zinc cause cell deformations like swelling (Table 2).

\section{DISCUSSION}

Protists are a large and diverse group of eukaryotic microorganisms, which belong to the kingdom Protista. Their reactions on heavy metals are various, such as reduction in food uptake, inhibition of growth, immobilization and at last reduction in rate of cell divisions, what can impact directly on their survival (Nilsson, 1981). On the other hand, heavy metals can affect the survival of protists in a variety of ways, for example, they can concentrate in the cell membranes and destroy the membrane integrity, which will ultimately result in cell lysis. Heavy metals can also block enzymes working or inactivate them (Albergoni and Piccinni, 1983). Some metals like copper, nickel and zinc which were used in this study, though they are components of cells, at certain concentrations can be able to do harm. In this study, the lethal concentration of nickel (II) chloride was $5 \times 10^{-5} \mathrm{~g} / \mathrm{dm}^{3}$ and $5 \times 10^{-3} \mathrm{~g} / \mathrm{dm}^{3}$ of zinc chloride. Madoni (1999) described a behavior of ciliates after nickel addition and listed many symptoms, such as fall of the velocity of swimming, diminution of spiralization, slowdown of rotary movement round the long body axis. After the next few minutes ciliates started crawling and stopped more frequently. In the immobilization phase cilia of the whole cell work but without performing an effective stroke. After a short while from the beginning of incubation in nickel (II) chloride we could observe the fall of the velocity of swimming, swimming backward, pivoting, circling and forward movement to a new direction. Nickel is known as one of the most effective immobilization agents for protozoa (Bovee, 1958). Gelei in 1935 also described the immobilizing action of $\mathrm{Ni}^{2+}$ salts upon Paramecium caudatum. The avoiding reaction, which is also typical for ciliates and characterized by reversal of ciliary beat and swimming backwards, pivoting, circling and turning to the aboral side of the body and forward movement to the new direction, was clearly described by Jennings (1906). Kuźnicki revealed immobilization of Paramecium caudatum and defined this immobilization as short reversions at intervals of several seconds. Those reversions involved quick withdrawals of the ciliates $1 / 2-2 / 3$ of their body length, and then a quick return to previous position (1963). The reactions mentioned above indicates other changes of cell preceding the deformation and death of a cell. Grebecki and Kuźnicki (1961) observed that after changes of swimming behavior, the macronucleus becomes distinctly visible, vacuoles enlarge and the cell starts to deform. In our study, the time after which cells began to change differs depending on the concentration of nickel, but deformed the faster, if the concentration was higher (Table 1).

Table 1 Effects of different concentration of nickel (II) chloride on a cell of Paramecium bursaria within 120 hours from the beginning of incubation of microscopic observation

\begin{tabular}{|c|c|c|c|c|c|c|c|c|}
\hline \multicolumn{9}{|l|}{ Cell reactions } \\
\hline $\begin{array}{l}\text { Concentration } \\
\text { of nickel }\end{array}$ & $\begin{array}{l}\text { Initial } \\
\text { number } \\
\text { of cells }\end{array}$ & $\begin{array}{c}\text { Cell } \\
\text { number } \\
\text { after } 24 \mathrm{~h}\end{array}$ & $\begin{array}{c}\text { Cell } \\
\text { number } \\
\text { after } 48 \mathrm{~h}\end{array}$ & $\begin{array}{c}\text { Cell } \\
\text { number } \\
\text { after } 72 \mathrm{~h}\end{array}$ & $\begin{array}{c}\text { Cell } \\
\text { number } \\
\text { after } 120 \\
\mathrm{~h}\end{array}$ & $\begin{array}{l}\text { Avoiding } \\
\text { reaction } \\
\text { and rotary } \\
\text { movement }\end{array}$ & $\begin{array}{c}\text { Cell } \\
\text { immobilization }\end{array}$ & $\begin{array}{c}\text { Cell } \\
\text { deformation } \\
\text { and death }\end{array}$ \\
\hline Control sample & 3 & 3 & 3 & 6 & 15 & - & - & - \\
\hline $5 \times 10^{-2} \mathrm{~g} / \mathrm{dm}^{3}$ & 3 & 3 & 3 & 3 & 3 & At once & At once & $\begin{array}{c}\text { After a few } \\
\text { seconds }\end{array}$ \\
\hline $5 \times 10^{-3} \mathrm{~g} / \mathrm{dm}^{3}$ & 3 & 3 & 3 & 3 & 3 & At once & After 2 minutes & $\begin{array}{c}\text { After 5 } \\
\text { minutes }\end{array}$ \\
\hline $5 \times 10^{-4} \mathrm{~g} / \mathrm{dm}^{3}$ & 3 & 3 & 3 & 3 & 3 & At once & After 10 minutes & $\begin{array}{l}\text { After } 20 \\
\text { minutes }\end{array}$ \\
\hline $5 \times 10^{-5} \mathrm{~g} / \mathrm{dm}^{3}$ & 3 & 3 & 3 & 3 & 3 & $\begin{array}{l}\text { After 10 } \\
\text { minutes }\end{array}$ & After 30 minutes & $\begin{array}{c}\text { After one } \\
\text { hour }\end{array}$ \\
\hline $5 \times 10^{-6} \mathrm{~g} / \mathrm{dm}^{3}$ & 3 & 3 & 3 & 6 & 6 & - & - & - \\
\hline $5 \times 10^{-7} \mathrm{~g} / \mathrm{dm}^{3}$ & 3 & 3 & 3 & 6 & 13 & - & - & - \\
\hline $5 \times 10^{-8} \mathrm{~g} / \mathrm{dm}^{3}$ & 3 & 3 & 3 & 6 & 14 & - & - & - \\
\hline
\end{tabular}


Table 2 Effects of different concentration of zinc chloride on a cell of Paramecium bursaria within 120 hours from the beginning of incubation of microscopic observation

\begin{tabular}{|c|c|c|c|c|c|c|c|c|c|}
\hline \multicolumn{10}{|l|}{ Cell reactions } \\
\hline $\begin{array}{l}\text { Concentration } \\
\text { of zinc }\end{array}$ & $\begin{array}{l}\text { Initial } \\
\text { number } \\
\text { of cells }\end{array}$ & $\begin{array}{c}\text { Cell } \\
\text { number } \\
\text { after } \\
24 \mathrm{~h}\end{array}$ & $\begin{array}{c}\text { Cell } \\
\text { number } \\
\text { after } \\
48 \mathrm{~h}\end{array}$ & $\begin{array}{c}\text { Cell } \\
\text { number } \\
\text { after } \\
72 \mathrm{~h}\end{array}$ & $\begin{array}{c}\text { Cell } \\
\text { number } \\
\text { after } \\
120 \mathrm{~h}\end{array}$ & $\begin{array}{l}\text { Avoiding } \\
\text { reaction } \\
\text { and rotary } \\
\text { movement }\end{array}$ & $\begin{array}{l}\text { Cell } \\
\text { color }\end{array}$ & $\begin{array}{c}\text { Cell } \\
\text { immobilization }\end{array}$ & $\begin{array}{c}\text { Cell } \\
\text { deformation } \\
\text { and death }\end{array}$ \\
\hline $\begin{array}{l}\text { Control } \\
\text { sample }\end{array}$ & 3 & 3 & 3 & 7 & 16 & - & Green & - & - \\
\hline $5 \times 10^{-2} \mathrm{~g} / \mathrm{dm}^{3}$ & 3 & 3 & 3 & 3 & 3 & At once & $\begin{array}{l}\text { Gray } \\
\text { after } \\
24 \mathrm{~h}\end{array}$ & At once & $\begin{array}{l}\text { After a few } \\
\text { seconds }\end{array}$ \\
\hline $5 \times 10^{-3} \mathrm{~g} / \mathrm{dm}^{3}$ & 3 & 3 & 3 & 3 & 3 & At once & $\begin{array}{l}\text { Dark } \\
\text { green } \\
\text { after } \\
48 \mathrm{~h}\end{array}$ & $\begin{array}{l}\text { After } 15 \\
\text { minutes }\end{array}$ & $\begin{array}{l}\text { After } 5 \\
\text { minutes }\end{array}$ \\
\hline $5 \times 10^{-4} \mathrm{~g} / \mathrm{dm}^{3}$ & 3 & 3 & 3 & 4 & 6 & $\begin{array}{l}\text { After } 5 \\
\text { minutes }\end{array}$ & Green & - & - \\
\hline $5 \times 10^{-5} \mathrm{~g} / \mathrm{dm}^{3}$ & 3 & 3 & 3 & 5 & 8 & $\begin{array}{l}\text { After } 10 \\
\text { minutes }\end{array}$ & Green & - & - \\
\hline $5 \times 10^{-6} \mathrm{~g} / \mathrm{dm}^{3}$ & 3 & 3 & 3 & 6 & 9 & - & Green & - & - \\
\hline $5 \times 10^{-7} \mathrm{~g} / \mathrm{dm}^{3}$ & 3 & 3 & 3 & 7 & 13 & - & Green & - & - \\
\hline $5 \times 10^{-8} \mathrm{~g} / \mathrm{dm}^{3}$ & 3 & 3 & 3 & 7 & 14 & - & Green & - & - \\
\hline
\end{tabular}

The toxicity of nickel compounds and effects on ciliates differ between various species. Madoni (1999) revealed the smallest toxicity towards Euplotes patella with concentration values between 6 and $10 \mathrm{mg} / \mathrm{L}$ and the greatest toxicity was observed for Spirostomum teres $(0,13-0,25 \mathrm{mg} / \mathrm{L})$. Higher sensitivity was observed in two species of Paramecium ( $P$. caudatum and P. bursaria). These organisms had a similar reaction on nickel with lethal doses of $0,36 \mathrm{mg} / \mathrm{L}$ and $0,49 \mathrm{mg} / \mathrm{L}$. Our second used metal, zinc is considered to be less toxic than other heavy metals. Madoni (1992) determined toxicities of four metals: cadmium, copper, mercury and zinc towards seven species of ciliates. Zinc was less toxic to the seven ciliate species than the other tested metals. The order of toxicity of the four metals to the seven ciliate species tested was generally: $\mathrm{Cu}>\mathrm{Hg}>\mathrm{Cd}>\mathrm{Zn}$. For six species the 24-h $\mathrm{LC}_{50}$ values for zinc were similar and ranged from 1,05 to $3,10 \mathrm{mg} / \mathrm{L}$. E. patella showed very low sensitivity to zinc, reaching a $24-\mathrm{h}$ $\mathrm{LC}_{50}$ value of $50 \mathrm{mg} / \mathrm{L}$. Parker (1979) reported a 24-h $\mathrm{LC}_{50}$ value of $192 \mathrm{mg} \mathrm{Zn/L}$ to the marine ciliate $U$. marinum. In our study Paramecium bursaria was also less sensitive to zinc than to nickel and the lethal dose was $5 \times 10^{-3} \mathrm{~g} / \mathrm{dm}^{3}$ (for nickel $5 \times 10^{-5} \mathrm{~g} / \mathrm{dm}^{3}$ ). The zinc was also responsible for decrease of cell divisions Euplotes vannus showed a $10 \%$ inhibition of cell division at $10 \mathrm{mg} / \mathrm{L}$ of zinc chloride (Persoone and Uyttersprot, 1975). The inhibition of cell division in microorganisms by heavy metals may be due to their interference with the synthesis and functioning of enzymes and other macromolecules (Eichorn, 1975). In our study zinc chloride caused the cell changes like swelling. Nilsson (2003) also described this issue as an increase of volume of the cell because of a rapid entry of the metal and increasing the intracellular concentration. We also observed a color changing in the lethal dose and above it from green to gray, which can indicate the storage reaction of endosymbionts of Paramecium bursaria. An interesting issue observed after zinc addition is a cell immobilization. Immobility of Tetrahymena, associated with rocking movements of the cells, was a gradual effect developing within 30 minutes and strongly indicates an interference of $\mathrm{Zn}$ with $\mathrm{Ca}$ metabolism (Nilsson, 2003). Availability and change in the intracellular ionic Ca concentration play an important role in the proper functioning of ciliary movement (Machemer, 1988). In our study we also observed an immobilization of cells after zinc addition and this reaction depended of course on zinc chloride concentration.

Statistical analysis revealed that both compounds: nickel (II) chloride and zinc chloride are responsible for the increasing activity of photosynthetic apparatus. The highest values of Fv/Fm, comparing to the control sample, were noticed after a 24-hour incubation in the least concentration (Fig. 1; Fig. 2). That can indicate the stimulating role of nickel and zinc ions to the photosynthetic apparatus. This phenomenon requires further and more advanced investigation.

\section{CONCLUSION}

Conclusions we can put forward are that nickel and zinc are toxic to freshwater ciliate Paramecium bursaria. Moreover nickel is an effective immobilizatory agent for ciliates and that both compounds ions are responsible for increasing activity of photosynthetic apparatus.

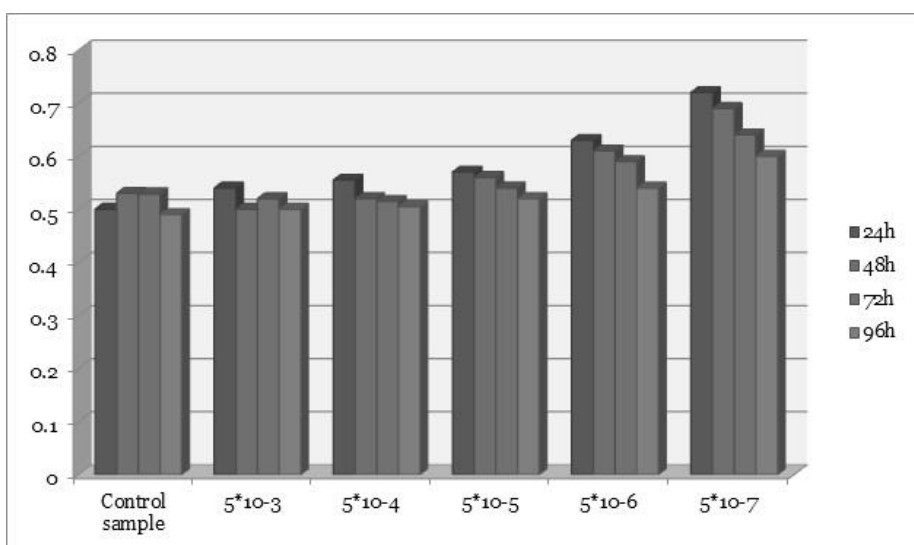

Figure 1 The influence of different concentrations of nickel (II) chloride to activity of photosynthetic apparatus $(\mathrm{Fv} / \mathrm{Fm})$ of endosymbionts of Paramecium bursaria within four days

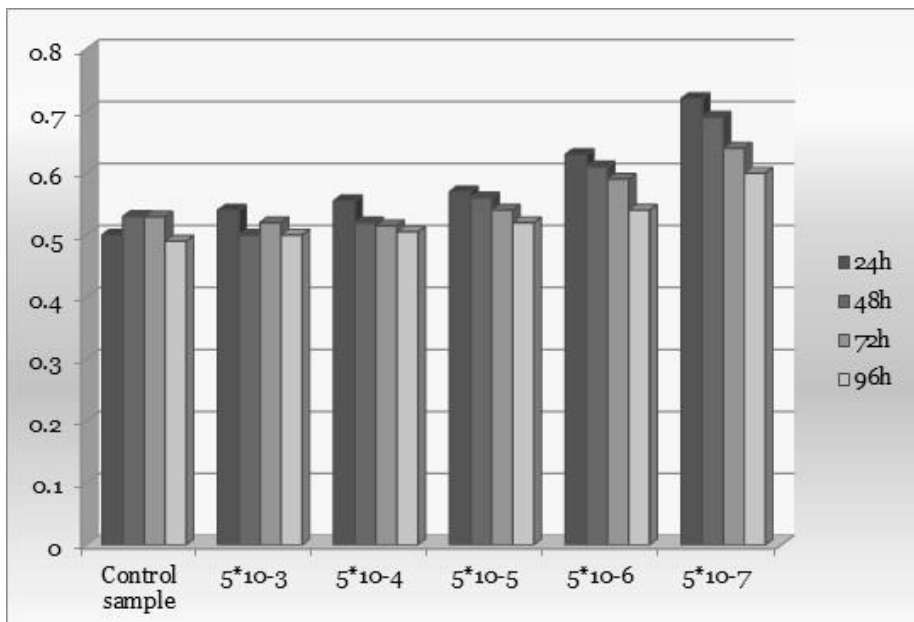

Figure 2 The influence of different concentrations of zinc chloride to activity of photosynthetic apparatus (Fv/Fm) of endosymbionts of Paramecium bursaria within four days

\section{REFERENCES}

ALBERGONI V., PUCCINNI E. 1983. Biological response to trace metals and their biochemical effects. In: Trace element speciation in surface water and its ecological implications. Leppard G. G. (Ed.), 159-174. ISBN: 978-1-4684-82362. http://dx.doi.org/10.1007/978-1-4684-8234-8_10

AL-MJENI F. A. 2002. Structural investigations of nickel metalloproteins: The Nik system (NikA and NikR), acireductone dioxygenase and hydrogenase. UMassAmherst, $\quad$ paper http://search.proquest.com/docview/305524671
AAI3068532. 
BOVEE E. 1958. Nickel sulfate as an anesthetic for protozoa. Turtox News, 36 78.

CAIRNS Jr., HART K. M., HENEBRY M. S., 1980. The effects of a sublethal dose of copper sulfate on the colonization rate of freshwater protozoan communities. The American Midland Naturalist, 104, 93-101.

CARPENE E., ANDREANI G., ISANI G. 2007. Metallothionein functions and structural characteristics. J. Trace Elem. Med. Biol. 21, 35-39. http://dx.doi.org/10.1016/j.jtemb.2007.09.011

CEMPEL M., NIKEL G. 2005. Nickel: A Review of Its Sources and Environmental Toxicology. Polish J. of Environ. Stud., 15, 375-382.

DAR S., SHUJA R. N., SHAKOORI A. R. 2013. A synthetic cadmium metallothionein gene (PMCd1syn) of Paramecium species: expression, purication and characteristics of metallothionein protein. Molecular Biology Reports, 40 983-997. http://dx.doi.org/10.1007/s11033-012-2140-8

DRYL S. 1973. Chemotaxis in ciliate Protozoa. Behaviour of Microorganisms, Warsaw, 16-30.

EICHORN G. L. 1975. Active sites of biological macromolecules and their interaction with heavy metals. In: Ecological toxicology research. MCINTYRE A. D., MILLS C. F. (Eds.). London: Plenum Press, 123-142.ISBN: 978-1-46158947-1. http://dx.doi.org/10.1007/978-1-4615-8945-7 6

FRAILE A., PENCHE S., GONZALES F., BLAZQUES M. L., MUNOZ J. A., BALLESTER A. 2005. Biosorption of copper, zinc, cadmium and nickel by Chlorella vulgaris. Chemistry and Ecology, 21, 61-75. http://dx.doi.org/10.1080/02757540512331334933

GELEI J. 1935. Ni-Infusorien im dienste der Forschung und des Unterrichtes. Biol. Zbl., 55, 57-74

GREBECKI A., KUŹNICKI L. 1961. Immobilization of Paramecium caudatum in the chloral hydrate solutions. Bull. Acad. Pol. Sci., S. Sci. Biol., 9, 459-462. HOSHINA R., HAYASHI S., IMAMURA N. 2009. Origins of algal symbionts of Paramecium bursaria. In: Endosymbionts in Paramecium. Fujishima M. (Ed.), 12, 1-29. http://dx.doi.org/10.1016/0014-4827(60)90005-7

JENNINGS H. S. 1906. Behavior of the lower organisms, 366. http://dx.doi.org/10.5962/bhl.title.4123

KUŹNICKI L. 1963. Reversible immobilization of Paramecium caudatum evoked by nickel ions. Acta protozool., 1, 301-313.

LENNTECH, 2010. Chromium Sourced 2010. Retrieved from: http://www.lenntech.com/periodic/elements/cr.htm, (Accessed on: May 31, 2010).

LESTER J.N. 1983. Significance and behavior of heavy metals in waste water treatment processes. I. Sewage treatment and effluent discharge. The science of the total environment, 30, 1-44.http://dx.doi.org/10.1016/0048-9697(83)90002-5 LEPEDUS H., BRKIC I., CESAR V., JURKOVIC H., ANTUNOVIC J., JAMBROVIC A., BRKIC J., SIMIC D. 2012. Chlorophyll fluorescence analysis of photosynthetic performance in seven maize inbred lines under water-limited conditions. Period boil., 114, 73-75

LYNN D.H. 2008. The ciliated Protozoa. Characterization, classification and guide and literature. $3^{\text {rd }}$ ed. Springer Publ, New York.

Machemer H. 1988. Motor control of cilia. In: Paramecium (Ed. H.-D. Görtz) Springer Verlag, Berlin, 216-235. http://dx.doi.org/10.1007/978-3-642-73086$\underline{3 \_14}$

MADONI P., ESTEBAN G., GORBI G. 1992. Acute Toxicity of Cadmium, Copper, Mercury, and Zinc to Ciliates from Activated Sludge Plants. Bull. Environ. Contam. Toxicol. 49, 900-905. http://dx.doi.org/10.1007/BF00203165

MADONI P. 1999. The acute toxicity of nickel to freshwater ciliates Environmental pollution, 109, 53-59. http://dx.doi.org/10.1007/BF00203165

NAPPI R. 2014. Colostrum: characteristics and role in the management of vulvovaginal atrophy.

In Focus. Springer Healthcare Italia S.r.1.

NICOLAU A., MOTA M., LIMA N. 1999. Physiological responses of Tetrahymena pyriformis to copper, zinc, cyclohexymide and Triton X-100, FEMS Microbiol. Ecol. 30, 209-216. http://dx.doi.org/10.1111/j.15746941.1999.tb00649.x

NILSSON J. R. 1981. Effect of copper on phagocytosis in Tetrahymena. Protoplasma, 109, 359-370. http://dx.doi.org/10.1007/BF01287453

NILSSON J. R. 2003. How Cytotoxic is Zinc? A Study on Effects of Zinc on Cell Proliferation, Endocytosis, and Fine Structure of the Ciliate Tetrahymena. Acta Protozool. 42, $19-29$.

PARKER J.G. 1979. Toxic effects of heavy metals upon cultures of Uronema madnum (Ciliophora: Uronematidae). Mar. Biol. 54, 17-24.

PERSOONE G., UYTTERSPROT G. 1975. The influence of inorganic and organic pollutants on the rate of reproduction Of a marine hypotrichous ciliate: Euplotes vannus Muller. Revue int. Oceanogr. med. 37, 125-151.

SONNEBORN T. M. 1970. Methods in Paramecium bursaria research. In: Methods in cell physiology. Prescott D. M. (Ed.), 241-339.

http://dx.doi.org/10.1016/S0091-679X(08)61758-6

TORRES F., GRACAS M., MELO M., TOSTI A. 2009. Management of contact dermatitis due to nickel allergy: an update. Clinical, Cosmetic and Investigational Dermatology, 2, 39-48.

VALLEE B. L., FALCHUK H. 1993. The biochemical basis of zinc physiology.

Physiol. Rev. 73, 79-118.
VALLEE B. L., MARET W. 1993. The functional potential and potential functions of metallothioneins. In: A personal perspective. In: Methallothionein III. Suzuki K. T., Imura N., Kimura N. (Eds.), Birkhäuser Verlag, Basel, 1-27.

$\mathrm{VAS}^{\sim}{ }^{\prime} \mathrm{K}$ M. Advances in metallothionein structure and functions. J. Trace Elem. Med. Biol., 19, 13-7. http://dx.doi.org/10.1016/i.jtemb.2005.03.003

VIOLANTE A., COZZOLINO V., PERElOMOV L., CAPORALE A. G. PIGNA M. 2010. Mobility and bioavailability of heavy metals and metalloids in soil environments. J. Soil. Sci. Plant Nutr. 10 (3), 268 - 292 http://dx.doi.org/10.4067/S0718-95162010000100005

WASE D. A. J., FORSTER C. F., Yo Y. S. 1997. Biosorbent for metal ions. Low-cost absorbent in continuous proceses, 141-163. 